\title{
Rapid detection of Chattonella marina by PCR combined with dot lateral flow strip
}

\author{
Chunyun Zhang ${ }^{1,2,3} \cdot$ Qixin Chen ${ }^{1} \cdot$ Fuguo Liu $^{1,2} \cdot$ Yin Liu $^{1} \cdot$ Yuanyuan Wang ${ }^{1} \cdot$ Guofu Chen $^{1,2,4}$
}

Received: 13 August 2021 / Revised and accepted: 30 November 2021 / Published online: 21 January 2022

(c) The Author(s), under exclusive licence to Springer Nature B.V. 2021

\begin{abstract}
In this study a novel technique referred to as PCR combined with dot lateral flow strip (PCDS) is proposed and its application to the detection of harmful microalgae was explored. For this purpose, using Chattonella marina as a test algal species, PCR targeting the D1-D2 region of large subunit ribosomal gene of this alga was performed with the tagged specific primers. The amplicons were then analyzed with the manually prepared dot lateral flow strip, and the strip could produce a test dot and a control dot that are naked-eye detectable, indicating the successful establishment of PCDS. The established PCDS assay does not require expensive instruments for the detection, and the results can be observed visually after adding $7.5 \mu \mathrm{L}$ of PCR amplicons in combination with $92.5 \mu \mathrm{L}$ of chromatography buffer to the sample pad of the strip for about $10 \mathrm{~min}$. The PCR conditions were optimized to enhance the effectiveness of detection. The cross-reactivity test with 23 microalgae species, including Chattonella marina, showed good specificity of the PCDS. The detection limit of PCDS was $1.25 \times 10^{-2}{\mathrm{ng} \mu \mathrm{L}^{-1}}^{-1}$ for genomic DNA and $10^{1}$ cells $\mathrm{mL}^{-1}$ for crude cell extracts, which can meet the detection needs. In summary, the PCDS proposed in this study has low cost, clear, and intuitive detection results and good specificity and sensitivity, providing a novel detection method for C. marina.
\end{abstract}

Keywords Chattonella marina $\cdot$ Raphidophyceae $\cdot$ PCR $\cdot$ Dot lateral flow strip $\cdot$ Detection

\section{Introduction}

Harmful algal blooms (HABs) refer to natural phenomena of mass propagation of algal cells in a short period due to the eutrophication of seawater, which usually can cause massive mortality of aquatic animals (Foss et al. 2019). In recent years HABs have become an increasingly serious environmental problem and pose a threat to human health (Huang et al. 2018) and sustainable development of the marine economy (Wang et al. 2017a). Therefore, it is essential to

Guofu Chen

chenguofu@hitwh.edu.cn

1 College of Oceanology, Harbin Institute of Technology (Weihai), Weihai 264209, People's Republic of China

2 School of Environment, Harbin Institute of Technology, Harbin 264209, People's Republic of China

3 School of Marine Sciences, Ningbo University, Ningbo 315211, People's Republic of China

4 School of Marine Science and Technology, Harbin Institute of Technology at Weihai, Wenhua West Road, Weihai 2\#, Shandong Province, China establish effective and convenient techniques for the early detection of harmful algae to take timely and effective measures to reduce the potential economic damage caused by HABs.

Chattonella marina, as a member of Raphidophyceae, is a highly adaptable marine harmful microalga. This algal species can live in a wide range of temperatures $\left(15-30{ }^{\circ} \mathrm{C}\right)$ and salinities (10-35 psu) (Yamaguchi et al. 1991). Chatonella marina is highly resistant to harsh environmental conditions and even can survive under an irradiance of up to about $1000 \mu \mathrm{mol}$ photons $\mathrm{m}^{-2} \mathrm{~s}^{-1}$ (Qiu et al. 2013). Chatonella marina can produce a variety of metabolites such as neurotoxins, hemolysins toxins, and reactive oxygen, and thus the HABs triggered by this alga can usually cause mass mortality of fish (Shimasaki et al. 2021). In recent years, great economic losses to aquaculture caused by $C$. marina-forming HABs have been reported in Korea (Kim et al. 2007), Japan (Onitsuka et al. 2011), Europe (Waite and Lindahl, 2006), and China (Wang et al. 2017b). Therefore, it is important to establish efficient and sensitive detection methods for $C$. marina. 
To date, the internationally recognized standards for the identification of microalgae are based on the morphological characteristics of the cells, including traditional microscopic observation and automatic image recognition by combining microscopic observation with computer technology. However, the traditional microscopic observation that is dependent on morphological structures has several limitations, such as low efficiency, poor timeliness, and high requirements for working personnel. Although these drawbacks have been overcome to some extent by automatic image recognition, this technique is not suitable for point-of-care testing (POCT) as it relies on flow cytometry and is therefore costly.

Since the 1980s, nucleic acid-based molecular techniques have been gradually applied to detect harmful algae. Several molecular detection techniques for HABs have been developed so far, including fluorescence in situ hybridization (FISH) (Miller and Scholin 2000; Liu et al. 2020), sandwich hybridization (SH) (Diercks et al. 2008; Zhu et al. 2012), polymerase chain reaction (PCR) (Lyu et al. 2017; Elleuch et al. 2020), isothermal amplification (IA) (Toldrà et al. 2019a; Zhang et al. 2019), microarrays (Taylor et al. 2013; Noyer et al. 2015), biosensors (Diercks-Horn et al. 2011; Toldrà et al. 2019b), and real-time qPCR (Nishimura et al. 2016; Zhang et al. 2016). These molecular detection techniques have, to a certain extent, overcome the disadvantages of traditional morphological identification methods, greatly improved the detection efficiency, and provided new ideas for the monitoring and early warning of HABs.

The lateral flow strip is a relatively new molecular detection technique that has been applied in many different areas due to its simplicity and sensitivity. In the field of food detection, Suryoprabowo et al. (2021) achieved the semi-quantitative detection of tadalafil, an illicit drug in coffee samples, using a lateral flow immunoassay based on a fluorescently labeled monoclonal antibody. Yao et al. (2021) used chromatographic strips for the simultaneous detection of fipronil and its metabolites in eggs and cucumbers. In the medical field, Takarada et al. (2020) combined the chromatographic strip technique with loop-mediated isothermal amplification (LAMP) for the rapid detection of rifampicin-resistant Mycobacterium tuberculosis. Zhang et al. (2020) developed a lateral flow strip for the rapid detection of SARS-CoV-2 based on a double antibody sandwich principle, which can be used as a diagnostic aid for the COVID-19 pandemic. Based on the above examples, the lateral flow strip can be combined with a variety of nucleic acid detection techniques to achieve qualitative or even semi-quantitative detection results. Therefore, combining the lateral flow strip with existing detection techniques for HABs is a promising idea.

Up to now, the molecular detection methods targeting $C$. marina mainly include multiplex polymerase chain reaction (mPCR) (Sun et al. 2019), quantitative polymerase chain reaction (qPCR) (Park et al. 2012), hyperbranched rolling circle amplification (HRCA) (Nie et al. 2017), loop-mediated isothermal amplification (LAMP) (Qin et al. 2019), double probes rolling circle amplification (dpRCA) (Qin et al. 2020), and membrane-based DNA array (Zhang et al. 2018). To initially establish the lateral flow strip technique for the detection of $C$. marina, PCR amplification combined with the lateral flow strip was chosen in this study.

Although the lateral flow strip technique is efficient and intuitive for nucleic acid analysis, the preparation of lateral flow strips requires special instruments and is relatively costly, which can significantly increase the detection cost especially when the number of samples to be tested is large. Therefore, in this study, we developed a hand-prepared dot lateral flow strip (DLFS) and investigated its application to detect harmful microalgae in combination with PCR. To achieve these objectives, the PCR combined with DLFS (PCDS) was firstly developed by using the sequence of large subunit D1-D2 (LSU D1-D2) as the target gene. Secondly, the PCR system and the detection conditions of the DLFS were optimized. Finally, the specificity, sensitivity, and practicality of the developed PCDS were also evaluated.

\section{Materials and methods}

\section{Algal species and culture}

Chatonella marina and control microalgal species used in this study are listed in Table 1. These algal species were obtained by micropipette isolation, purchased from commercial companies, or kindly donated as gifts. The algal culture conditions were as follows: (1) the culture medium was $f / 2$ (for diatoms) or $f / 2$-Si medium (Guillard 1975) with a $\mathrm{pH}$ of 8.2 prepared from filtered and sterilized seawater; (2) all of the algal cultures were grown at $20-24^{\circ} \mathrm{C}$, with a light intensity of 50-100 $\mu \mathrm{mol}$ photons $\mathrm{m}^{-2} \mathrm{~s}^{-1}$, and a lightto-dark ratio of $12 \mathrm{~h}: 12 \mathrm{~h}$; and (3) all of the cultures were shaken regularly once or twice per day, with culture medium renewed every 2-3 weeks for good growth.

\section{DNA extraction}

Aliquots (45 mL) of C. marina cultures in the logarithmic growth phase were subjected to centrifugation $(4000 \times g$ for $10 \mathrm{~min}$ at $4{ }^{\circ} \mathrm{C}$ ), and then the resulting cell pellets were washed once under the same centrifugation conditions as above. Genomic DNA was extracted from the obtained algal cells using the Ezup Column Plant Genomic DNA Extraction Kit (Sangon Biotech, China). The concentration of

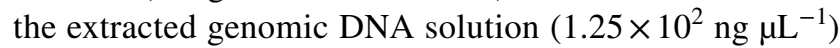
was determined using a NAS-99 microspectrophotometer (Thermo Fisher Scientific, USA). The purity of genomic DNA was evaluated by the ratio of absorbance at $260 \mathrm{~nm}$ 
Table 1 List of algal species used in this study and results of PCR-dot chromatography strip (PDCS) using the specially designed probes/primers for Chattonella marina

\begin{tabular}{|c|c|c|c|}
\hline Species & Taxonomy & Geographic origin & $\begin{array}{l}\text { Analysis } \\
\text { by PDCS }\end{array}$ \\
\hline Chattonella marina & Raphidophyceae & Daya Bay, South China Sea & $+^{\mathrm{a}}$ \\
\hline Heterosigma akashiwo & Raphidophyceae & South China Sea & $-{ }^{b}$ \\
\hline Phaeocystis globosa & Prymnesiophyceae & South China Sea & - \\
\hline Dierateria zhanjiangensis & Prymnesiophyceae & Xiamen Bay, East China Sea & - \\
\hline Isochrysis galbana & Eustigmatophyceae & East China Sea & - \\
\hline Alexandrium catenella & Dinophyceae & East China Sea & - \\
\hline Alexandrium tamarense & Dinophyceae & East China Sea & - \\
\hline Prorocentrum lima & Dinophyceae & Daya Bay, South China Sea & - \\
\hline Prorocentrum minimum & Dinophyceae & Daya Bay, South China Sea & - \\
\hline Alexandrium minutum & Dinophyceae & Hongkong, South China Sea & - \\
\hline Ellipsoidion sp. & Dinophyceae & East China Sea & - \\
\hline Prorocentrum micans & Dinophyceae & Weihai Bay, Yellow Sea & - \\
\hline Scrippsiella trochoidea & Dinophyceae & South China Sea & - \\
\hline Karlodinium veneficum & Dinophyceae & East China Sea & - \\
\hline Prorocentrum donghaiense & Dinophyceae & Zhejiang, East China Sea & - \\
\hline Amphidinium carterae & Dinophyceae & East China Sea & - \\
\hline Karenia mikimotoi & Dinophyceae & Wenzhou,East China Sea & - \\
\hline Chlorella vulgaris & Chlorophyceae & Bohai Sea & - \\
\hline Chaetoceros mиelleri & Bacillariophyceae & Weihai Bay, Yellow Sea & - \\
\hline Pseudo-nitzschia pungens & Bacillariophyceae & Zhujiang Estuary, East China Sea & - \\
\hline Nitzschia closterium f.minutissima & Bacillariophyceae & Weihai Bay, Yellow Sea & - \\
\hline Thalassiosira pseudonana & Bacillariophyceae & Taiwan Strait, West Pacific Ocean & - \\
\hline Phaeodactylum tricornutum & Bacillariophyceae & East China Sea & - \\
\hline
\end{tabular}

$\left(A_{260}\right)$ to that at $280 \mathrm{~nm}\left(A_{280}\right)$. The obtained DNA samples were subjected to $1 \%$ agarose gel electrophoresis (AGE) and stored at $-20{ }^{\circ} \mathrm{C}$.

\section{Primers and probes}

The primers used for the PCDS assay consist of three parts, i.e., tag sequence, spacer, and specific sequence. The specific sequences for the forward and reverse primers were obtained from Sun et al. (2019), and the tag sequences Tgn and Tsp, as well as the probes cTsp, Tgn, and cTgn, were obtained from Nagai et al. (2016). All the probes and primers used in this study are summarized in Table 2 and were synthesized by Sangon Biotech (Shanghai) Co., Ltd. In particular, the gold nanoparticle probe cTgn was labeled with a sulfhydryl (SH) group at the $5^{\prime}$ end to allow it to bind to the gold nanoparticles. In addition, a poly $\left(A_{16}\right)$-tail labeled with biotin was added to the $5^{\prime}$ end of the detection probe cTsp and the control probe Tgn. The purpose of the biotin labeling is to enable the probes to bind to the anti-biotin antibody to form large molecules for attachment to the detection membrane of the test strip, and the addition of the poly $\left(A_{16}\right)$ tail is to prevent encapsulation of the probe sequence when the biotin binds to the anti-biotin antibody.

\section{Principle and detection process of the PCDS}

The schematic diagram principle of the PCDS is shown in Fig. 1. The detection process consists of two stages, namely, PCR amplification and nucleic acid chromatography. In the PCR amplification phase, since both the forward primer Cm-Fp with Tgn and the reverse primer Cm-Rp with Tsp contain Spacer 9 that can effectively prevent the extension of DNA polymerase when the specific sequence triggers PCR amplification, they will produce the PCR products with double tags (Tgn and Tsp). In the nucleic acid chromatography phase, the PCR products are first mixed with chromatography buffer and added to the sample pad. Due to capillary action, the mixture flows laterally to the conjugate pad, where the tag sequence Tgn can be complementarily bound to the gold nanoparticlelabeled probe (cTgn), thus allowing the PCR products to form a complex with the gold nanoparticle. Next, the unbound gold nanoparticle-labeled probe and the complex mentioned above continue to laterally flow to the test 
Table 2 Summary of primers/probes used in this study

\begin{tabular}{llll}
\hline Primer/probe & Sequence $\left(5-3^{\prime}\right)$ & Reaction & Sources \\
\hline D1 & ACCCGCTGAATTTAAGCATA & PCR & Scholin et al. (1994) \\
D2 & CCTTGGTCCGTCTTTCAAGA & PCR & Sun et al. (2019) \\
Cm-F & CTTGGTTGTTGTAGCGTCTT & PCR & PCR \\
Cm- $\mathrm{R}^{\mathrm{b}}$ & GAGAGAGTGAGGTCAGCAGA & PDCS & This study \\
$\mathrm{Cm}-\mathrm{Fp}^{\mathrm{c}}$ & attttcactgggtttatagt-iSp9-CTTGGTTGTTGTAGCGTCTT & PDCS & This study \\
$\mathrm{Cm}-\mathrm{Rp}^{\mathrm{c}}$ & tcgagtgacagctaatgtgtgatt-iSp9-GAGAGAGTGAGGTCAGCAGA & PDCS & Nagai et al. (2016) \\
$\mathrm{cTgn}^{\mathrm{d}}$ & SH-ACTATAAACCCAGTGAAAAAT & PDCS & \\
$\operatorname{Tgn}^{\mathrm{e}}$ & Bio-Poly(dA)-ATTTTTCACTGGGTTTATAGT & PDCS & \\
$\mathrm{cTsp}^{\mathrm{f}}$ & Bio-Poly(dA)-AATCACACATTAGCTGTCACTCGA & \\
\hline
\end{tabular}

${ }^{\mathrm{a}} \mathrm{Cm}-\mathrm{F}$ is forward primer

${ }^{\mathrm{b}} \mathrm{Cm}-\mathrm{R}$ is reverse primer

${ }^{\mathrm{c}}$ The uppercase letters of primer sequence represent the necessary part for PCR amplification of the LSU rDNA of Chattonella marina, and the lowercase letters represent tag sequence

${ }^{\mathrm{d}}$ The probe cTgn is labeled with $\mathrm{SH}$ at the $5^{\prime}$ end

${ }^{\mathrm{e}}$ The probe Tgn is labeled with biotin at the $5^{\prime}$ end

${ }^{\mathrm{f}}$ The probe cTsp is labeled with biotin at the $5^{\prime}$ end

dot site on the detection membrane, where the test probe cTsp can complementarily bind to the tag sequence Tsp, producing a red test dot due to the aggregation chromogenic effect of gold nanoparticles. Finally, the free gold nanoparticle-labeled probe continues to flow laterally to the control dot site, where cTgn binds to the preset control probe Tgn, again producing a red control dot due to the aggregation of gold nanoparticles.

For the practical application of the PCDS, $7.5 \mu \mathrm{L}$ of PCR amplification products were first mixed with $92.5 \mu \mathrm{L}$ of chromatography buffer. Then, the sample pad of the prepared DLFS was dipped into the mixture. After 5-10 min, the detection result was determined by observing whether red dots can be produced at the test and control dot sites or not. A positive result is determined when two red dots are produced at both the test and control dot sites, and a negative result is determined when only one red dot is produced at the control dot site. If no red spot appears in both the test and control spot sites, the test strip detection system is proven to be not working effectively.

\section{Preparation of DLFS}

\section{Preparation of the sample pad}

The glass fiber SB06 (Shanghai Liangxin Technology Co., Ltd.) used as the sample pad was immersed in sample pad buffer $(0.05 \mathrm{M}$ Tris-HCl, $0.15 \mathrm{M} \mathrm{NaCl}, 0.25 \%$ Triton $\mathrm{X}-100$; $\mathrm{pH}$ 8.0) for $20 \mathrm{~min}$, dried at $37^{\circ} \mathrm{C}$ for $2 \mathrm{~h}$ and then stored at room temperature (RT).

\section{Preparation of the conjugate pad}

The solution containing gold nanoparticles with an average diameter of approximately $30 \mathrm{~nm}$ was prepared by the citrate reduction method (Turkevich and Enüstun 1963; Yeh et al. 2012). Aliquots ( $1 \mathrm{~mL})$ of gold nanoparticle solution were centrifuged at $12,000 \times g$ for $20 \mathrm{~min}$ at RT. After removing the supernatant, $6 \mu \mathrm{L}$ of $100 \mu \mathrm{M}$ gold nanoparticle probe (cTgn) and $94 \mu \mathrm{L}$ of $1 \times \mathrm{TE}$ buffer were added to the precipitate, mixed well, and incubated at $4{ }^{\circ} \mathrm{C}$ for $12 \mathrm{~h}$. An equal volume $(100 \mu \mathrm{L})$ of PBS solution $(0.2 \mathrm{M} \mathrm{NaCl}, 20 \mathrm{mM}$ $\mathrm{Na}_{2} \mathrm{HPO}_{4} / \mathrm{NaH}_{2} \mathrm{PO}_{4} ; \mathrm{pH} 7.0$ ) was added, mixed quickly, and incubated at $4{ }^{\circ} \mathrm{C}$ for $24 \mathrm{~h}$. The solution was centrifuged at RT for $10 \mathrm{~min}$ at $2000 \times g$. After removing the supernatant, the precipitate was resuspended with $200 \mu \mathrm{L}$ of ultrapure water and centrifuged again under the same conditions to remove the unlabeled probes. Finally, the resultant gold nanoparticle-labeled probe was resuspended with $1 \mathrm{~mL}$ of embedding buffer $\left(20 \mathrm{mM} \mathrm{Na}_{3} \mathrm{PO}_{4}, 5 \%\right.$ BSA, $0.25 \%$ Triton $\mathrm{X}-100,8 \%$ sucrose) and stored at $4{ }^{\circ} \mathrm{C}$ away from light. When in use, the above-stored gold nanoparticle-labeled probe solution was first thoroughly dispersed by ultrasound under lightproof conditions, then uniformly sprayed onto glass fiber RB65 (Shanghai Liangxin Technology Co., Ltd.) (ca. $0.18 \mathrm{~mL} \mathrm{~cm}^{-2}$ ), dried at $37^{\circ} \mathrm{C}$ for $2 \mathrm{~h}$, and stored at RT.

\section{Preparation of detection membrane}

The nitrocellulose membrane (NCM) (Sartorius UniSart CN140 Membrane) used as the detection membrane was successively immersed in $\mathrm{ddH}_{2} \mathrm{O}$ for $10 \mathrm{~min}$ and in $20 \times \mathrm{SSC}$ 


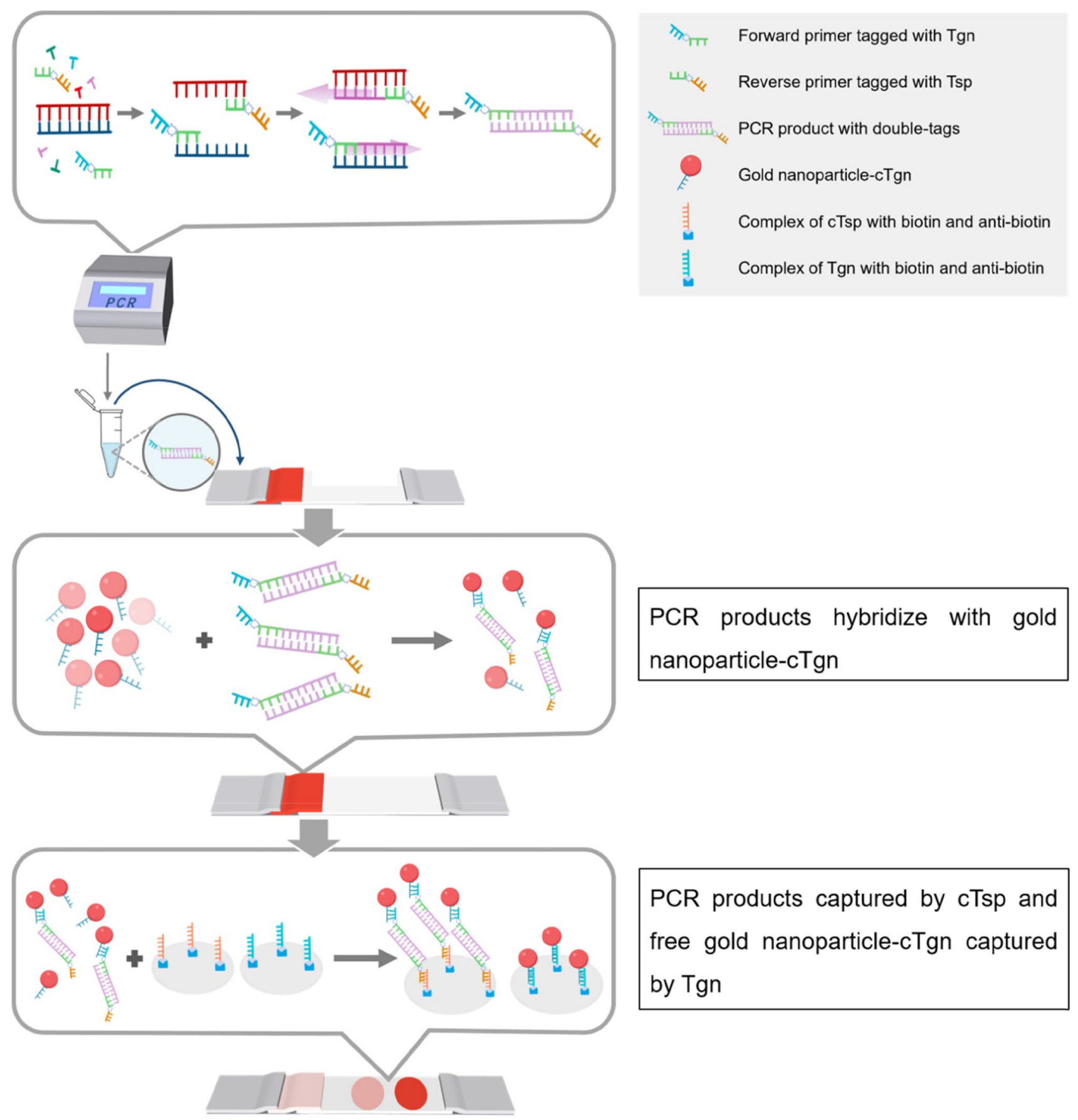

Fig. 1 Schematic diagram of detection principle of PDCS

solution $\left(\mathrm{NaCl}, 17.5322 \mathrm{~g} ; \mathrm{Na}_{3} \mathrm{C}_{6} \mathrm{H}_{5} \mathrm{O}_{7} .2 \mathrm{H}_{2} \mathrm{O}, 8.823 \mathrm{~g}\right.$; $\mathrm{ddH}_{2} \mathrm{O}, 100 \mathrm{~mL} ; \mathrm{pH}$ 7.0) for $5 \mathrm{~min}$, and then dried in the air. Next, anti-biotin antibody (Cell Signaling Technology) was mixed, respectively, with the test probe (cTsp) and the control probe (Tgn) $(10 \mu \mathrm{M})$ with a volume ratio of 1 to 10 , and aliquots $(1 \mu \mathrm{L})$ of the mixture was spotted onto the test and control sites (approximately $7 \mathrm{~mm}$ apart). The spotted NCM was then UV cross-linked (UV cross-linker setting: wavelength, $254 \mathrm{~nm}$; intensity, $90 \mathrm{~J} \mathrm{~cm}^{-2}$ ) for 2 min to bind the probe to the NCM firmly.

\section{Test strip assembly}

The schematic diagram of the assembly of DLFS is as shown in Fig. 2. In brief, the detection membrane was first pasted on the PVC base (SM31-40) (Shanghai Liangxin 
Fig. 2 Schematic diagram of the structure of DLFS

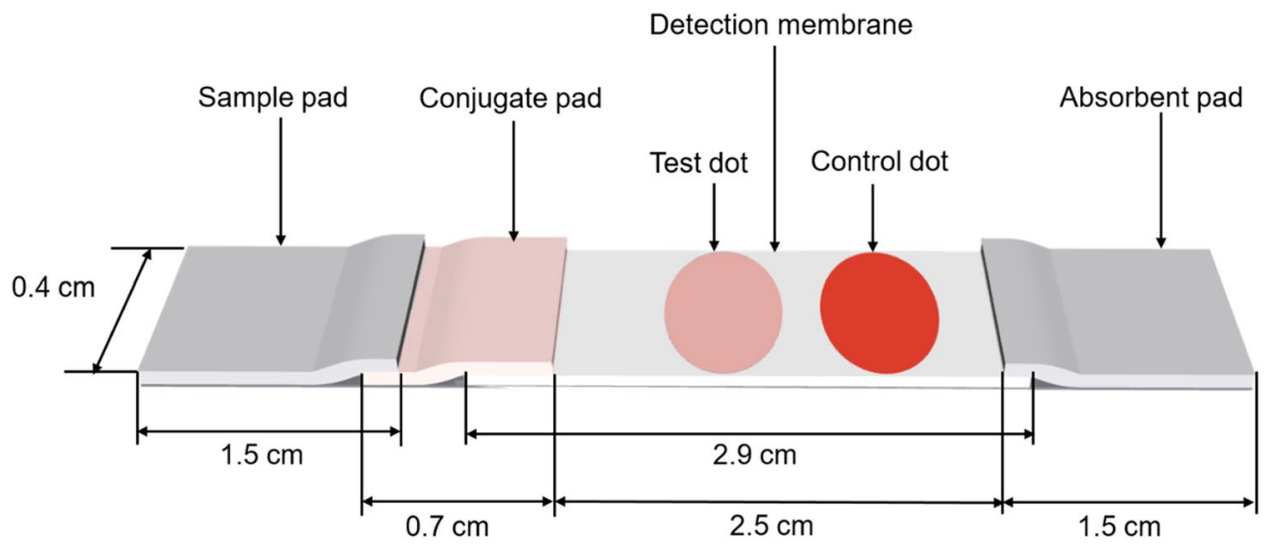

Technology Co., Ltd.). Then, the conjugate pad near the test spot and the absorbent pad (CH27) (Shanghai Liangxin Technology Co., Ltd.) near the control spot were attached to each end of the detection membrane with a $2 \mathrm{~mm}$ overlap. In addition, the sample pad was paste on the other side of the conjugate pad with a $2 \mathrm{~mm}$ overlap.

\section{Optimization of specific PCR conditions and detection system}

Specific PCR was performed in a thermal cycler (Bioer Technology, China) with a total volume of $12.5 \mu \mathrm{L}$ consisting of $1 \times$ PCR buffer $(1.25 \mu \mathrm{L}), 2.5 \mathrm{mM} \mathrm{MgCl}_{2}(0.75 \mu \mathrm{L})$, $0.4 \mathrm{mM}$ dNTP mix $(1 \mu \mathrm{L}), 0.4 \mathrm{mM}$ primers $(\mathrm{Cm}-\mathrm{Fp}$ and Cm-Rp, 0.25 $\mu \mathrm{L}$ each), 0.2 U Taq polymerase (Sangon Biotech, China) $(0.1 \mu \mathrm{L})$, and $12.5 \mathrm{ng}$ genomic DNA $(1 \mu \mathrm{L})$. The amplification procedure was as follows: $94{ }^{\circ} \mathrm{C}$ for $5 \mathrm{~min} ; 29$ cycles of $94{ }^{\circ} \mathrm{C}$ for $45 \mathrm{~s}, 55^{\circ} \mathrm{C}$ for $30 \mathrm{~s}$, and $72{ }^{\circ} \mathrm{C}$ for $50 \mathrm{~s}$; and a final extension at $72{ }^{\circ} \mathrm{C}$ for $7 \mathrm{~min}$. The PCR products were analyzed by $1.5 \%$ AGE.

After the initial establishment of the PCR system, various PCR conditions, including annealing temperatures $\left(55^{\circ} \mathrm{C}\right.$, $57{ }^{\circ} \mathrm{C}, 59^{\circ} \mathrm{C}, 61^{\circ} \mathrm{C}, 63^{\circ} \mathrm{C}$, and $65^{\circ} \mathrm{C}$ ), primer concentrations $(0.05 \mu \mathrm{M}, 0.10 \mu \mathrm{M}, 0.15 \mu \mathrm{M}, 0.20 \mu \mathrm{M}, 0.25 \mu \mathrm{M}$, and $0.30 \mu \mathrm{M}), \mathrm{Mg}^{2+}$ concentrations $(0 \mathrm{mM}, 0.5 \mathrm{mM}, 1.0 \mathrm{mM}$, $1.0 \mathrm{mM}, 1.5 \mathrm{mM}, 2.0 \mathrm{mM}$, and $2.5 \mathrm{mM}$ ) were optimized by comparative testing. Each parameter was tested with other conditions unchanged. The optimized conditions were used in the subsequent tests.

\section{Specificity test of PCDS}

A total of 23 microalgal species (Table 1), including the target species, were selected for a cross-reactivity test to verify the specificity of the established PCDS. In brief, universal PCR amplification was first performed using the genomic DNA from all the test species as templates with the previously reported primers D1 and D2 (Scholin et al. 1994) (Table 2) to determine whether the template quality was suitable for subsequent specific PCR with the primers $\mathrm{Cm}-\mathrm{Fp}$ and Cm-Rp. Second, the same genomic DNA mentioned above was used as test samples for specific PCR and PCDS, respectively. The PCR products were analyzed by $2 \%$ AGE, and the results of the PCDS were judged by observing the presence or absence of colored dots on the test and control spot sites of DLFS.

\section{Sensitivity test of PCDS}

The sensitivity of PDCS was tested using the genomic DNA of $C$. marina as a template. The genomic DNA prepared in the subsection "DNA extraction" was diluted tenfold with nuclease-free water (Sangon Biotech (Shanghai) Co., Ltd.) to prepare DNA test samples in a gradient of seven con-

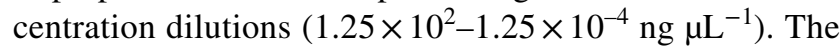
test samples were analyzed by PCDS, with the specific PCR as control. The specific PCR was performed with primers $\mathrm{Cm}-\mathrm{Fp}$ and $\mathrm{Cm}-\mathrm{Rp}$. The PCR products were analyzed by $1.5 \%$ AGE, and the results of the PCDS were determined by observing the coloration results of DLFS.

\section{Analysis of spiked samples by PCDS}

The natural seawater that was used to prepare spiked samples was collected from Jinhai Bay (Weihai, Shandong, China) in the Yellow Sea, in which no microalgal target cell could be observed by microscopic examination. Aliquots of $C$. marina cultures in the exponential growth stage were fixed with $1.5 \%$ Luger's solution, and the cell concentration was determined by counting with a plankton counting chamber under light microscopy. The $C$. marina cells that were collected from $50 \mathrm{~mL}$ of algal culture by centrifugation $\left(4^{\circ} \mathrm{C}, 4000 \times g\right.$, and $\left.10 \mathrm{~min}\right)$ were resuspended in $50 \mathrm{~mL}$ of natural seawater, which was used as the initial spiked sample with a concentration of $10^{5}$ cells $\mathrm{mL}^{-1}$. Then, the initial sample was tenfold diluted with natural seawater to result in a series of spiked samples with the concentration range of $10^{5}-10^{-1}$ cells $\mathrm{mL}^{-1}$. Algal cells were, respectively, 
collected from these spiked samples by centrifugation using the same conditions as above, and DNA extracts were prepared using One-tube Plant Genome DNA Extraction Kit (Sangon Biotech, China) according to the manufacturer's instructions. The obtained crude DNA extracts were used as templates for specific PCR and the PCDS, respectively.

\section{Results}

\section{Optimization of PCR conditions and probe amount}

The PCR conditions, including annealing temperature, primer concentration, and $\mathrm{Mg}^{2+}$ concentration were optimized to gain high amplification efficiency with a minimum yield of primer dimer. The optimization results of annealing temperature are shown in Fig. S1. When the annealing temperature was higher than $63{ }^{\circ} \mathrm{C}$, no target band could be detected by AGE, indicating that the PCR could not occur. In comparison, when the annealing temperature was between 55 and $59^{\circ} \mathrm{C}$, clear target bands could be detected by AGE, indicating that efficient PCR could occur. Therefore, the optimal annealing temperature was finally set at $55{ }^{\circ} \mathrm{C}$ to reduce primer dimers. Next, the primer concentration was optimized by setting the annealing temperature at $55{ }^{\circ} \mathrm{C}$ (Fig. S2). Successful PCR amplification could occur with all primer concentrations. In addition, a much higher amplification efficiency could be detected with the primer concentration of $0.15,0.20,0.25$, and $0.30 \mu \mathrm{M}$, respectively. The optimal final primer concentration was set to $0.15 \mu \mathrm{M}$ to save costs and reduce primer dimer. Finally, the $\mathrm{Mg}^{2+}$ concentration was optimized by setting the annealing temperature at $55^{\circ} \mathrm{C}$ and the primer concentration at $0.15 \mu \mathrm{M}$ (Fig. S3). Because a much higher amplification efficiency could be detected with the $\mathrm{Mg}^{2+}$ concentrations of 1.5, 2.0, and $2.5 \mathrm{mM}$, respectively, the optimal $\mathrm{Mg}^{2+}$ concentration was set to $1.5 \mathrm{mM}$ to save costs.

Based on the above results, the optimal PCR conditions (Table 3) were applied to perform PCR amplification (Fig. 3A). The resultant PCR products were subjected to DLFS (Fig. 3B) in triplicate by setting the probe amount at both test and control spot sites to $10 \mathrm{pM}$. Three independent tests consistently showed that although DLFS could work well, i.e., the positive samples could produce red dots at

Table 3 Summary of the optimized conditions for PCR

\begin{tabular}{ll}
\hline Conditions & Result \\
\hline Annealing temperature & $55^{\circ} \mathrm{C}$ \\
Cm-Fp concentration & $0.15 \mu \mathrm{M}$ \\
Cm-Fp concentration & $0.15 \mu \mathrm{M}$ \\
$\mathrm{Mg}^{2+}$ concentration & $1.5 \mathrm{mM}$ \\
\hline
\end{tabular}

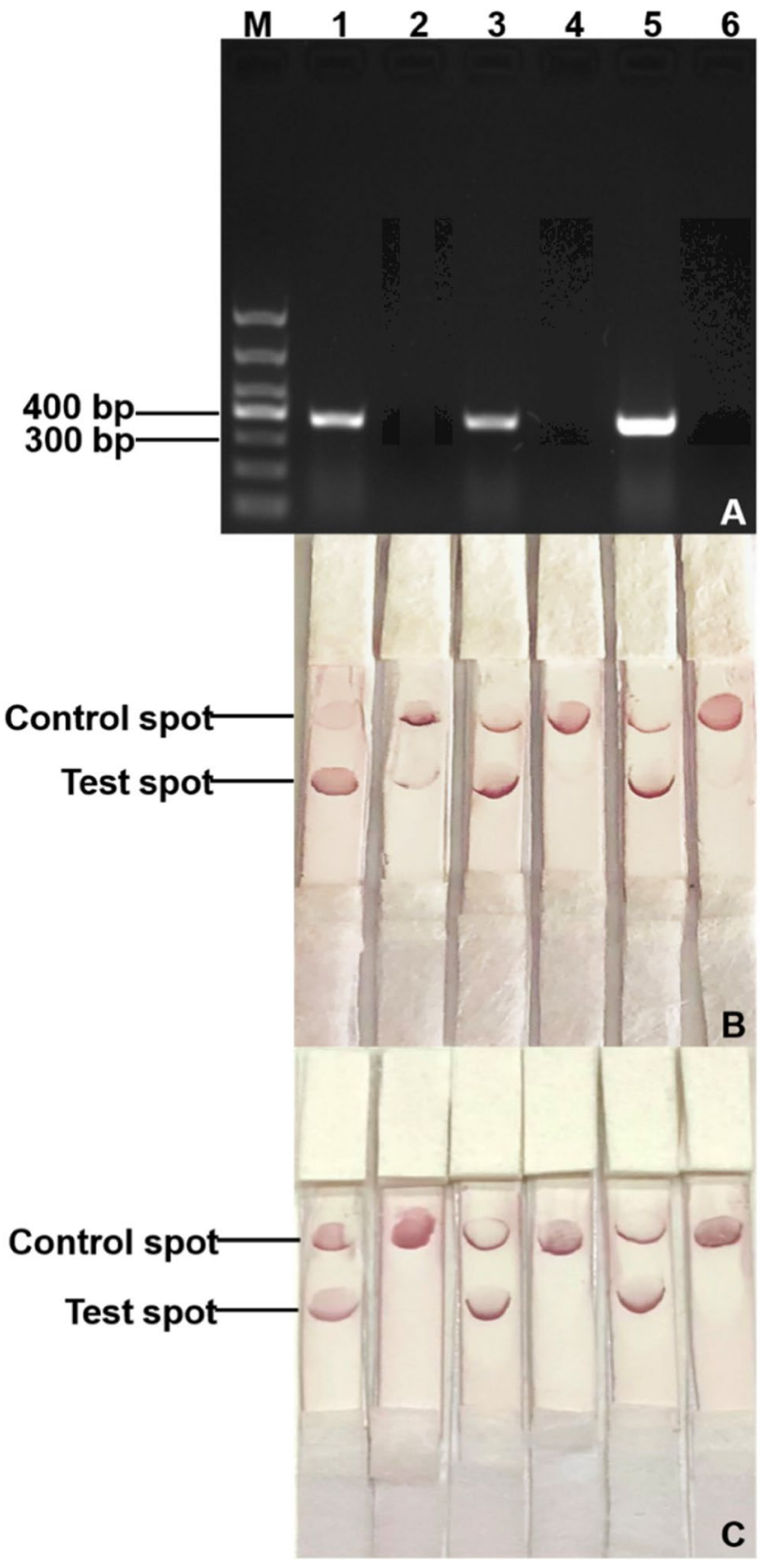

Fig. 3 Optimization of PCR conditions and probe amount for DLFS. A AGE analysis of PCR products; B PCDS analysis using the preliminarily prepared DLFS by setting the probe amount to $10 \mathrm{pM}$; C PCDS analysis using the optimized DLFS by setting the probe amount to $7.5 \mathrm{pM}$. M, DL 1000 DNA marker; lanes 1, 3, and 5 are PCR products; lanes 2, 4, and 6 are blank controls

both test and control spot sites of the strips, the blank control samples could also unexpectedly produce two light red dots at both test and control spot sites of the strips, which is actually a "false positive" result. Therefore, to further eliminate the "false positive" results, three parallel PCDS tests were performed by adjusting the amount of test probe to $7.5 \mathrm{pM}$ (Fig. 3C). Fortunately, all the tests produced the same results 
that indicate that "false positive" has been successfully eliminated, i.e., PCR amplification products could produce red dots at both test and control spot sites of DLFS, while blank control could produce red dots only at control spot sites.

\section{Specificity analysis of PCDS}

A total of 23 marine microalgal species, including $C$. marina, were selected for the cross-reactivity test to confirm the specificity of the established PCDS assay. First, the universal PCR amplification of the LSU rDNA D1-D2 region using the genomic DNA of all the algal species as the template consistently showed positive results, indicating that the quality of the DNA template for each species could meet the requirements of the amplification test (Fig. 4A). Second, specific PCR amplification using the $C$. marina-specific primers $\mathrm{Cm}-\mathrm{Fp} / \mathrm{Rp}$ was carried out, showing that successful PCR amplification could exclusively occur with only the genomic DNA from the target species (Fig. 4B). Finally, all the specific PCR amplification solutions (with or without PCR products) were subjected to a DLFS assay. The results showed that only the target species produced two red dots on the strips for test and control spot sites, whereas the non-target species and the blank control produced only one red spot on the strips for the control site (Fig. 4C). In conclusion, the PCDS assay developed in this study is specific for the detection of the target algal species.

\section{Sensitivity analysis of PCDS}

A series of tenfold dilutions of the target algal genomic DNA was used for comparative PCR-AGE and PCDS analysis using the specific primers Cm-Fp/Rp (Fig. 5), respectively. PCR-AGE and PCDS displayed a detection limit of $1.25 \times 10^{-1} \mathrm{ng} \mu \mathrm{L}^{-1}$ and $1.25 \times 10^{-2} \mathrm{ng} \mu \mathrm{L}^{-1}$ for genomic DNA. Therefore, PCDS is 10 times more sensitive than PCR-AGE.

\section{Assessment of the application of PCDS}

To assess the practicability of the established PCDS, spiked natural water samples containing target algal cells with the concentration range of $10^{5}-10^{-1}$ cells $\mathrm{mL}^{-1}$ were prepared and used as test samples for the comparative analysis by PCR-AGE and PCDS (Fig. 6). Positive PCR-AGE and PCDS results could be detected with the spiked samples with the

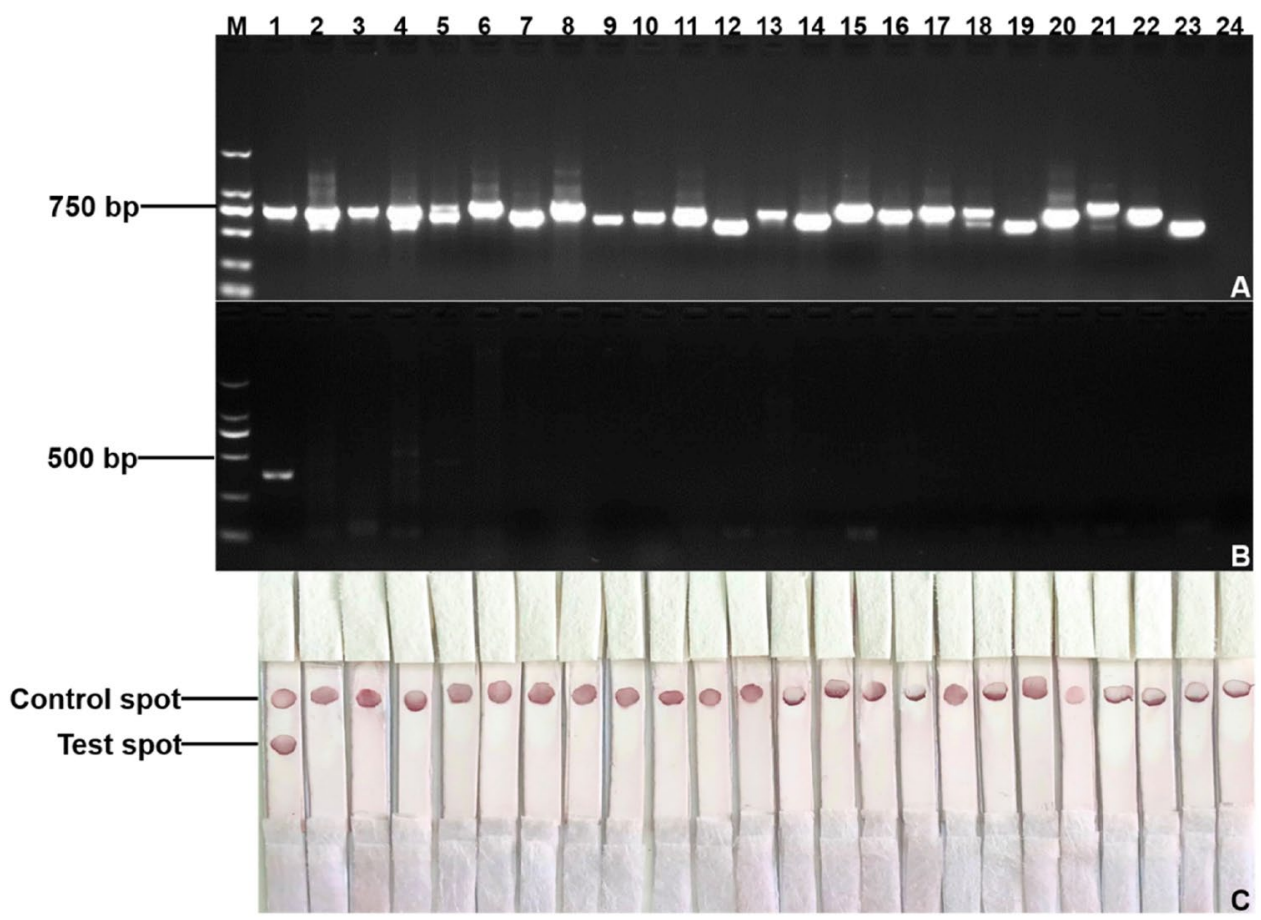

Fig. 4 Specificity validation of PCR primers $(\mathrm{Cm}-\mathrm{Fp} / \mathrm{Rp})$ and specificity test of PCDS. A AGE analysis of PCR products with the universal primers (D1/D2); B AGE analysis of PCR products with the specific primers $(\mathrm{Cm}-\mathrm{Fp} / \mathrm{Rp})$; C PCDS analysis. M, DL2000 DNA marker; lanes 1-23, the test algal species are Chattonella marina, Alexandrium catenella, Heterosigma akashiwo, A. tamarense, Chaetoceros muelleri, Pseudo-nitzschia pungens, Prorocentrum lima, P. minimum, A. minutum, Chlorella vulgaris, Ellipsoidion sp., Nitzschia closterium f.minutissima, P. micans, Scrippsiella trochoidea, Karlodinium veneficum, P. donghaiense, Thalassiosira pseudonana, Phaeodactylum tricornutum, Amphidinium carterae, Phaeocystis globosa, Isochrysis galbana, and Dierateria zhanjiangensis, respectively; lane 24, blank control 


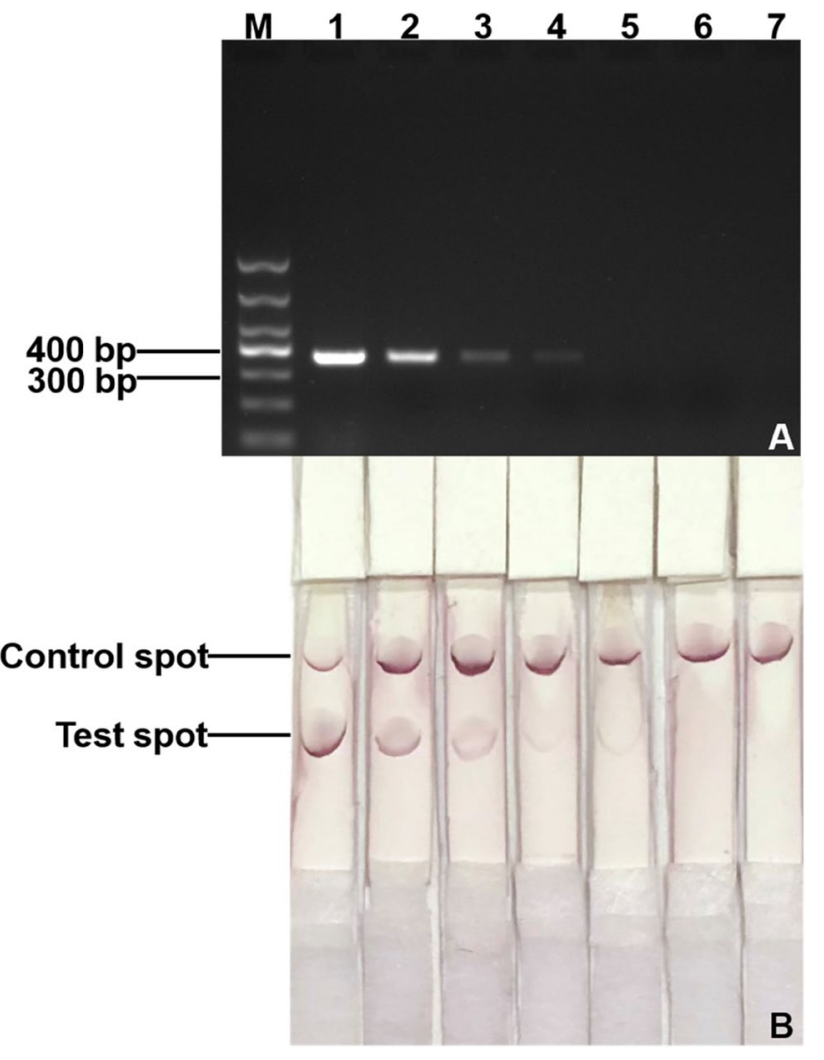

Fig. 5 Comparison of the sensitivity of PCR-AGE (A) and PCDS (B) with genomic DNA. M, DL1000 DNA marker; lanes 1-7, the concentrations of genomic DNA range from $1.25 \times 10^{2}$ to $1.25 \times 10^{-4} \mathrm{ng}$ $\mu \mathrm{L}^{-1}$

concentration ranges of $10^{5}-10^{2}$ cells $\mathrm{mL}^{-1}$ (Fig. 6A) and $10^{5}-10^{1}$ cells $\mathrm{mL}^{-1}$ (Fig. 6B), respectively. In other words, PCR-AGE and PCDS displayed a detection limit of $10^{2}$ cells $\mathrm{mL}^{-1}$ and $10^{1}$ cells $\mathrm{mL}^{-1}$, respectively. Again, the tests with spiked samples indicated that PCDS is 10 times more sensitive than PCR-AGE.

\section{Discussion}

Chatonella marina can produce several toxic metabolites such as reactive oxygen species (ROS), brevetoxin/brevetoxin-like compounds, free fatty acids (FFAs), hemagglutinins, and hemolysins (Shen et al. 2010), which may play a synergistic role in ichthyotoxicity and indirectly cause large-scale fish mortality (Qiu et al. 2020). In addition, $C$. marina may exert an allelopathic effect on other dinoflagellates, triggering larger-scale HABs and causing serious economic and ecological damage to the aquatic environment (Fernandez-Herrera et al. 2016). Therefore, it is important to establish a rapid detection method for $C$. marina to take effective measures to reduce costs before it causes serious damage.

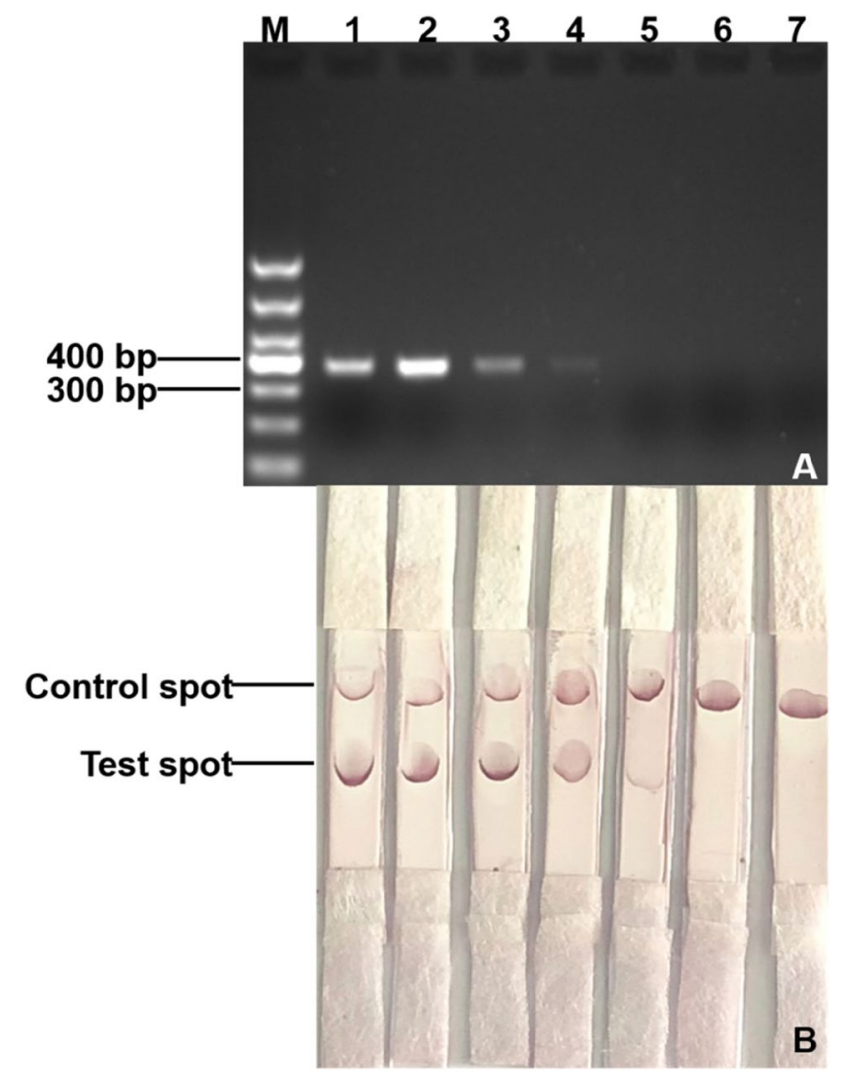

Fig. 6 Comparison of the sensitivity of PCR-AGE (A) and PCDS (B) with crude DNA extracts. M, DL1000 DNA marker; lanes 1-7, the crude DNA extracts prepared with the cell density ranging from $10^{5}$ to $10^{-1}$ cells $\mathrm{mL}^{-1}$

In this study, we try to establish a convenient, sensitive, and practical detection method for C. marina. The existing molecular detection methods developed for $C$. marina including mPCR, qPCR, HRCA, LAMP, dpRCA, and membrane-based DNA array have been proven to be effective but still have some limitations. For example, $\mathrm{mPCR}$ and qPCR require relatively high requirements for primer design, and qPCR requires expensive fluorescent dyes, leading to a relatively high detection cost. Although the isothermal amplification techniques such as LAMP, HRCA, and dpRCA are independent of thermal cyclers, the need for the key components such as DNA polymerase with strand-displacement activity, Bst polymerase, and phosphorylated probes can also increase the cost of the assay. The membrane-based DNA array is not suitable for POCT because of the complex experimental process and long test time. By contrast, neither complex experimental procedures nor expensive components are required for PCDS. In addition, the cost for PCDS that is prepared by hand is much lower compared with the traditional chromatography strip technology, which makes PCDS more competent for POCT. 
The selection of suitable target genes is vital for a molecular detection method. Noncoding internal transcribed spacer (ITS), LSU rDNA, and small subunit (SSU) rDNA sequences are often selected as molecular markers for the discrimination of algal species. The main reason for this is that these genes contain both conserved and highly variable regions, facilitating the design of primers or detection probes specific to different algal species (Xu et al. 2021). Also, both ITS and LSU rDNA have been used as the main target for most of the established molecular detection methods for $C$. marina. For example, Park et al. (2012) designed the primers targeting ITS for specific qPCR detection of $C$. marina. Kai et al. (2006) established a single-cell PCR assay using the LSU rDNA as a target to distinguish between two Chattonella species. In this study, the LSU rDNA sequence of $C$. marina was selected as the target, and based on the previously designed specific primers (Sun et al. 2019), the tag sequence was added and used for the establishment of the PCDS assay. The specificity experiments in this study in combination with previous studies again demonstrated the effectiveness of LSU rDNA for interspecies differentiation.

The overall optimization of the detection conditions is a crucial step in the development of an assay. According to the principle of PCDS, the production of primer dimers as a by-product of PCR can interfere with the determination of detection results, also known as "false positives." To eliminate the interference of "false positive," a series of control variables were optimized. First, the PCR conditions were optimized to avoid the production of primer dimer by successively determining the optimal annealing temperature $\left(55^{\circ} \mathrm{C}\right)$, primer concentration $(0.15 \mu \mathrm{M})$, and $\mathrm{Mg}^{2+}$ concentration $(1.5 \mathrm{mM})$. However, DLFS analysis of blank control with the optimized PCR conditions showed that "false positives" could still interfere with specific detection. Therefore, we tried to adjust the amount (sampling volume) of the test probe on the strip and tested again. Fortunately, "false positive" for the blank controls was successfully eliminated in this way.

Sensitivity is a critical factor that could reflect the practical application value of a detection method. Therefore, in this study, we evaluated the detection limit of the established PCDS assay. First, a comparative test was performed using the serially diluted genomic DNA as test samples, showing that the sensitivity of PCDS is one order of magnitude higher than that of PCRAGE. Spiked natural water samples were further employed to assess the detection limit of PCDS, which was determined to be 10 cells $\mathrm{mL}^{-1}$. In general, the sensitivity test with both the genomic DNA and the crude cell extracts consistently displayed that PCDS is an order of magnitude more sensitive than PCR-AGE. According to the previously reported results (Lee et al. 1995), the early warning concentration for the outbreak of $C$. marina-forming HABs is 200 cells $\mathrm{mL}^{-1}$, so the PCDS assay developed in this study can meet the practical needs. In addition, the sensitivity of PCDS is also comparable to that of the established molecular detection methods for $C$. marina including HRCA (Nie et al. 2017) and dpRCA-LFD (Qin et al. 2020).

In conclusion, a novel method referred to as PCDS was developed for the highly specific and sensitive detection of C. marina in this study. The developed PCDS could enable the efficient detection of $C$. marina, with the intuitive results visible to the naked eyes. In addition, the low cost of preparation of DLFS also gives PCDS an advantage in terms of in situ detection, making it an effective means of preventing HABs. In the future, DLFS could be combined with RPA to further shorten the detection time and make it suitable for use in resource-poor areas to really meet the requirements for POCT. In addition, DLFS can also be combined with mPCR or multiplex recombinase polymerase amplification to realize the multiple detections of harmful algae.

Supplementary Information The online version contains supplementary material available at https://doi.org/10.1007/s10811-021-02667-x.

Acknowledgements This work was supported by Shandong Provincial Natural Science Foundation, China (ZR2020MD081); the National Scientific Foundation of China (No. 31600309, 41476086); HIT Scientific Research Innovation Fund/the Fundamental Research Funds for the Central Universities (No. HIT.NSRIF.201702 and HIT.NSRIF.201709); and HIT Environment and Ecology Innovation Special Funds (No. HSCJ201622).

Data availability All data generated or analyzed during this study are included in this published article.

\section{References}

Diercks-Horn S, Metfies K, Jäckel S, Medlin LK (2011) The ALGADEC device: a semi-automated rRNA biosensor for the detection of toxic algae. Harmful Algae 10:395-401

Diercks S, Medlin LK, Metfies K (2008) Colorimetric detection of the toxic dinoflagellate Alexandrium minutum using sandwich hybridization in a microtiter plate assay. Harmful Algae 7:137-145

Elleuch J, Barkallah M, Smith KF, Ben Neila I, Fendri I, Abdelkafi S (2020) Quantitative PCR assay for the simultaneous identification and enumeration of multiple Karenia species. Environ Sci Pollut Res 27:36889-36899

Fernandez-Herrera LJ, Band-Schmidt CJ, Lopez-Cortes DJ, Hernandez-Guerrero CJ, Bustillos-Guzman JJ, Nunez-Vazquez E (2016) Allelopathic effect of Chattonella marina var. marina (Raphidophyceae) on Gymnodinium catenatum (Dinophycea). Harmful Algae 51:1-9

Foss AJ, Aubel MT, Gallagher B, Mettee N, Miller A, Fogelson SB (2019) Diagnosing microcystin intoxication of canines: clinicopathological indications, pathological characteristics, and analytical detection in postmortem and antemortem samples. Toxins (basel) 11:456

Guillard RRL (1975) Culture of phytoplankton for feeding marine invertebrates. In: Smith WL, Chanley MH (eds) Culture of marine invertebrate animals. Plenum Press, New York, pp 29-60

Huang X, Chen H, Xia F, Wang Z, Mei K, Shang X, Liu Y, Dahlgren RA, Zhang M, Huang H (2018) Assessment of long-term 
watershed management on reservoir phosphorus concentrations and export fluxes. Int J Environ Res Public Health 15:2169

Kai AKL, Cheung YK, Yeung PKK, Wong JTY (2006) Development of single-cell PCR methods for the Raphidophyceae. Harmful Algae 5:649-657

Kim SY, Seo KS, Lee CG, Lee Y (2007) Diurnal modification of a red-tide causing organism, Chattonella antiqua (Raphidophyceae) from Korea. Algae 22:95-106

Lee TY, Gotoh N, Niki E, Yokoyama K, Tsuzuki M, Takeuchi T, Karube I (1995) Chemiluminescence detection of red tide phytoplankton Chattonella-marina. Anal Chem 67:225-228

Liu YY, Hu ZX, Deng YY, Tang YZ (2020) Evidence for resting cyst production in the cosmopolitan toxic dinoflagellate Karlodinium veneficum and the cyst distribution in the China seas. Harmful Algae 93:101788

Lyu Y, Richlen ML, Sehein TR, Chinain M, Adachi M, Nishimura T, Xu Y, Parsons ML, Smith TB, Zheng T (2017) LSU rDNA based RFLP assays for the routine identification of Gambierdiscus species. Harmful Algae 66:20-28

Miller PE, Scholin CA (2000) On detection of Pseudo-nitzschia (Bacillariophyceae) species using whole cell hybridization: sample fixation and stability. J Phycol 36:238-250

Nagai S, Miyamoto S, Ino K, Tajimi S, Nishi H, Tomono J (2016) Easy detection of multiple Alexandrium species using DNA chromatography chip. Harmful Algae 51:97-106

Nie XL, Zhang CY, Wang YY, Guo CL, Zhou J, Chen GF (2017) Application of hyper-branched rolling circle amplification (HRCA) and HRCA-based strip test for the detection of Chattonella marina. Environ Sci Pollut Res 24:15678-15688

Nishimura T, Hariganeya N, Tawong W, Sakanari H, Yamaguchi H, Adachi M (2016) Quantitative PCR assay for detection and enumeration of ciguatera-causing dinoflagellate Gambierdiscus spp. (Gonyaulacales) in coastal areas of Japan. Harmful Algae 52:11-22

Noyer C, Abot A, Trouilh L, Leberre VA, Dreanno C (2015) Phytochip: development of a DNA-microarray for rapid and accurate identification of Pseudo-nitzschia spp and other harmful algal species. J Microbiol Meth 112:55-66

Onitsuka G, Aoki K, Shimizu M, Matsuyama Y, Kimoto K, Matsuo H, Kitadai Y, Nishi H, Tahara Y, Sakurada K (2011) Short-term dynamics of a Chattonella antiqua bloom in the Yatsushiro Sea, Japan, in summer 2010: characteristics of its appearance in the southern area. Bull Jpn Soc Fish Oceanogr 75:143-153

Park BS, Baek SH, Ki JS, Cattolico RA, Han MS (2012) Assessment of EvaGreen-based quantitative real-time PCR assay for enumeration of the microalgae Heterosigma and Chattonella (Raphidophyceae). J Appl Phycol 24:1555-1567

Qin Y, Chen GF, Zhang CY, Wang YY, Zhou J (2019) Development of loop-mediated isothermal amplification combined with a chromatographic lateral-flow dipstick for rapid detection of Chattonella marina. Harmful Algae 89:101666

Qin Y, Zhang CY, Liu FG, Chen QX, Yang YC, Wang YY, Chen GF (2020) Establishment of double probes rolling circle amplification combined with lateral flow dipstick for rapid detection of Chattonella marina. Harmful Algae 97:101857

Qiu X, Shimasaki Y, Tsuyama M, Yamada T, Kuwahara R, Kawaguchi M, Honda M, Gunjikake H, Tasmin R, Shimizu M (2013) Growth-phase dependent variation in photosynthetic activity and cellular protein expression profile in the harmful raphidophyte Chattonella antiqua. Biosci Biotech Biochem 77:46-52

Qiu XC, Chen C, Shimasaki Y, Mukai K, Teramoto A, Wu M, Oshima Y (2020) Time-series responses in photosynthetic activity, 2-cysteine peroxiredoxin gene expression, and proteomics of Chattonella marina var. antiqua under different oxidative stress. Harmful Algae 94:101808
Scholin CA, Herzog M, Sogin M, Anderson DM (1994) Identification of group-specific and strain-specific genetic-markers for globally distributed Alexandrium (Dinophyceae). 2. sequence-analysis of a fragment of the LSU ribosomal-RNA gene. J Phycol 30:999-1011

Shen M, Xu JL, Tsang TY, Au DWT (2010) Toxicity comparison between Chattonella marina and Karenia brevis using marine medaka (Oryzias melastigma): evidence against the suspected ichthyotoxins of Chattonella marina. Chemosphere 80:585-591

Shimasaki Y, Mukai K, Takai Y, Qiu X, Oshima Y (2021) Recent progress in the study of peroxiredoxin in the harmful algal bloom species Chattonella marina. Antioxidants (basel) 10:162

Sun YJ, Chen GF, Zhang CY, Guo CL, Wang YY, Sun R (2019) Development of a multiplex polymerase chain reaction assay for the parallel detection of harmful algal bloom-forming species distributed along the Chinese coast. Harmful Algae 84:36-45

Suryoprabowo S, Liu L, Kuang H, Cui G, Xu C (2021) Fluorescence based immunochromatographic sensor for rapid and sensitive detection of tadalafil and comparison with a gold lateral flow immunoassay. Food Chem 342:128255

Takarada Y, Kodera T, Kobayashi K, Nakajima C, Kawase M, Suzuki Y (2020) Rapid detection of rifampicin-resistant Mycobacterium tuberculosis, based on isothermal DNA amplification and DNA chromatography. J Microbiol Meth 177:106062

Taylor JD, Berzano M, Percy L, Lewis J (2013) Evaluation of the MIDTAL microarray chip for monitoring toxic microalgae in the Orkney Islands. UK Environ Sci Pollut Res 20:6765-6777

Toldrà A, O'Sullivan CK, Campàs M (2019a) Detecting harmful algal blooms with isothermal molecular strategies. Trends Biotechnol 37:1278-1281

Toldrà A, Alcaraz C, Diogène J, O'Sullivan CK, Campàs M (2019b) Detection of Ostreopsis cf. ovata in environmental samples using an electrochemical DNA-based biosensor. Sci Total Environ 689:655-661

Turkevich J, Enüstun B (1963) Coagulation of colloidal gold. J Am Chem Soc 85 (21): 3317-3328

Waite AM, Lindahl O (2006) Bloom and decline of the toxic flagellate Chattonella marina in a Swedish fjord. Mar Ecol: Prog Ser 326:77-83

Wang B, Tao Y, Liu Q, Liu N, Jin Z, Xu X (2017a) Algicidal activity of bacillamide alkaloids and their analogues against marine and freshwater harmful algae. Mar Drugs 15:247

Wang B, Wu D, Chu KH, Ye L, Yip HY, Cai Z, Wong PK (2017b) Removal of harmful alga, Chattonella marina, by recyclable natural magnetic sphalerite. J Hazard Mater 324:498-506

Xu YX, He XL, Li HL, Zhang T, Lei F, Gu HF, Anderson DM (2021) Molecular identification and toxin analysis of Alexandrium spp. in the Beibu Gulf: first report of toxic A. tamiyavanichii in Chinese Coastal Waters. Toxins 13:161

Yamaguchi M, Imai I, Honjo T (1991) Effects of temperature, salinity, and irradiance on the growth rates of the noxious red tides flagellates Chattonella antiqua and C. marina (Raphidophyceae). Nippon Suisan Gakkaishi 57:1277-1284

Yao J, Wang Z, Guo L, Xu X, Liu L, Kuang H, Xu C (2021) Lateral flow immunoassay for the simultaneous detection of fipronil and its metabolites in food samples. Food Chem 356:129710

Yeh YC, Creran B, Rotello VM (2012) Gold nanoparticles: preparation, properties, and applications in bionanotechnology. Nanoscale 4:1871-1880

Zhang C, Zhou L, Du K, Zhang Y, Wang J, Chen L, Lyu Y, Li J, Liu H, Huo J, Li F, Wang J, Sang P, Lin S, Xiao Y, Zhang K, He K (2020) Foundation and clinical evaluation of a new method for detecting SARS-CoV-2 antigen by fluorescent microsphere immunochromatography. Front Cell Infect Microbiol 10:553837

Zhang CY, Chen GF, Wang YY, Sun R, Nie XL, Zhou J (2018) MHBMDAA: membrane-based DNA array with high resolution and 
sensitivity for toxic microalgae monitoring. Harmful Algae 80:107-116

Zhang CY, Chen GF, Wang YY, Zhou J, Li CH (2019) Establishment and application of hyperbranched rolling circle amplification coupled with lateral flow dipstick for the sensitive detection of Karenia mikimotoi. Harmful Algae 84:151-160

Zhang CY, Chen GF, Zhou J, Wang YY, Lu DD (2016) Development of a quantitative PCR for detection and quantification of Prorocentrum donghaiense. J Appl Phycol 28:1683-1693
Zhu X, Zhen Y, Mi TZ, Yu ZG (2012) Detection of Prorocentrum minimum (Pavillard) Schiller with an electrochemiluminescencemolecular probe assay. Mar Biotechnol 14:502-511

Publisher's note Springer Nature remains neutral with regard to jurisdictional claims in published maps and institutional affiliations. 